\title{
Relationship Between a CEO's Level of Education and Corporate Social Responsibility: Evidence from Chinese Listed Firms
}

\author{
Yiming Ma ${ }^{1}$, Juncheng $\mathrm{Li}^{2}$, Lu Yang ${ }^{3}$, Yafeng $\mathrm{Hu}^{4}, \mathrm{Ke} \mathrm{Gao}^{5}$ \\ ${ }^{1}$ Chinese Academy of Finance and Development, Central University of Finance and Economics, Beijing, P. R. China \\ ${ }^{2}$ School of Finance, Central University of Finance and Economics, Beijing, P. R. China \\ ${ }^{3}$ School of Economics, Qingdao University, Qingdao, P. R. China \\ ${ }^{4}$ China Academy of Public Finance and Public Policy, Central University of Finance and Economics, Beijing, P. R. China \\ ${ }^{5}$ Development Research Center of Shandong Provincial People's Government, Jinan, P. R. China
}

\section{Email address:}

18511693068@163.com (Yiming Ma),2779583526@qq.com (Juncheng Li), YL70739804@163.com (Lu Yang), 15510680821@163.com (Yafeng Hu),gkfly@126.com(Ke Gao)

\section{To cite this article:}

Yiming Ma, Juncheng Li, Lu Yang, Yafeng Hu, Ke Gao. Relationship Between a CEO's Level of Education and Corporate Social Responsibility: Evidence from Chinese Listed Firms. International Journal of Business and Economics Research.

Vol. 8, No. 4, 2019, pp. 232-244. doi: 10.11648/j.ijber.20190804.18

Received: May 13, 2019; Accepted: July 24, 2019; Published: July 29, 2019

\begin{abstract}
This study investigates the influence of a CEO's level of education on the Corporate Social Responsibility (CSR) of listed firms in China. We find a significant and positive impact of the CEO's level of education on the CSR of a firm, one level promotion of CEOs' education will increase 0.1630 CSR scores of a firm and increase the probability of CSR disclosure by $10.75 \%$. This finding is robust for the univariable analysis and for sub-items and the forward performance of CSR. Further, we find that the positive relationship between the CEO's level of education and CSR is more pronounced for CEOs who also chair the board, state-owned firms and CEOs who have overseas experience. More concretely, when the CEO is also the chairman, the CEO's level of education has a greater positive effect on CSR than those are not chairman. In state-owned enterprises, the CEO's level of education plays a greater role in the positive promotion of the CSR than non-stated-owned enterprises. When the CEO has studied or worked abroad, the CEO's level of education has a greater positive effect on the CSR than those who do not have overseas experience. Our findings shed light on the role of the CEO's level of education in CSR, and our research on Chinese listed companies enriches the relevant research on CSR in developing countries.
\end{abstract}

Keywords: Corporate Social Responsibility, CEO’s Level of Education, CEO Duality, State Ownership, Overseas Experience

\section{Introduction}

The implementation of a sustainable development agenda is a common task of current international development cooperation and a shared responsibility of the international community. In the environment of sustainable development, scientific development and an environmentally friendly society, people have a new understanding of the nature and role of enterprises in the social system. As a member of the social system, enterprises are not only economic organizations that exist in order to obtain profits, but also actors that need to assume social responsibility and fulfill their social citizenship obligations. Since the 1980s, Corporate Social Responsibility (CSR) has attracted increasing attention around the world [1, 2], which has caused great repercussions and discussions in academic and industrial circles, and there have been growing calls from the government, the media and the public for companies to actively fulfill their social responsibilities. Through theoretical analysis and empirical analysis, some scholars have proved that the full implementation of social responsibility has become a compulsory course in the development of modern enterprises: on the one hand, the effective implementation of corporate social responsibility can enable enterprises to have predictable 
income in the future, and thus help enterprises to yield good economic performance $[3,4]$. On the other hand, the effective implementation of corporate social responsibility can help enterprises to establish a good social reputation, reduce the economic consequences of the company's risks, and thus obtain sustainable competitive advantages. On the contrary, it will harm the sustainable development of enterprises [5]. However, with the rapid growth of the world economy, the contradiction between economic and social development is becoming increasingly prominent, probing the causes and consequences of corporate social responsibility. Rational use of a CSR strategy to achieve economic benefits and social benefits of a win-win situation is an important subject worthy of our in-depth research and discussion.

At present, most of the studies on corporate social responsibility continue with the four-dimensional pyramid paradigm and stakeholder paradigm of Carroll (1979) [6], and most of the studies on how to fulfill corporate social responsibility are also based on the research of this paradigm. The vast majority of empirical research on corporate social responsibility focuses on the consequences of corporate social responsibility, such as the impact on financial value creation and brand reputation. However, the previous research on corporate social responsibility is generally limited, and its research content is mostly concerned with the institutional environment, industry competition, corporate characteristics and other aspects. Wood (1991) [7] believes that the existing corporate social responsibility paradigm still lacks a clear theory to elaborate on the role of senior managers in formulating corporate policies and undertaking social responsible behaviors. In the future, the research on the influence of entrepreneurs' personal characteristics on corporate social responsibility will become an important research trend. In this context, the analysis of the relationship between executive education and corporate social responsibility can offer important insight to corporates.

Finally, as the largest developing country in the world, the research based on Chief Executive Officer (CEO) characteristics and CSR of Chinese enterprises is of great value to the development and trend of CSR in developing countries.

\section{Literature Review}

\subsection{The Connotation and Influencing Factors of Corporate Social Responsibility}

In 1924, British scholar Sheldon first put forward the concept of "corporate social responsibility". He connected corporate social responsibility to the responsibility of corporate operators to meet a variety of human needs, both inside and outside the industry, and argued that corporate social responsibility contained ethical factors [8].

Corporate social responsibility refers to the fact that while making profits and assuming legal responsibilities to shareholders and employees, enterprises should also assume responsibilities to stakeholders, such as consumers, the environment and society $[9,10]$. Corporate social responsibility requires enterprises to go beyond the traditional concept of profit as the sole goal, emphasizing the need to pay attention to human value in the production process, emphasizing the contribution to consumers, the environment and society.

The degree and effect of corporate social responsibility performance are subject to the influence of many factors. At present, the research on the pre-factors of corporate social responsibility mainly consists of the following three aspects: First is the level of the institutional environment. The institutional environment outside the company will have an impact on the willingness and level of enterprises to fulfill their social responsibility; the better the institutional environment, the better the performance of corporate social responsibility. Second is the level of industry competition. In a highly competitive industry, enterprises may seek a chance of survival by reducing the safety and quality of products, firing employees, deceiving consumers and other ways, thus damaging the interests of stakeholders [11]. Additionally, in monopolistic industries, because consumers lack bargaining power and voice, enterprises do not need to achieve social responsibility to obtain consumer goodwill and trust, so too fierce or too little industry competition will reduce the willingness of enterprises to fulfill social responsibility. Third is the level of enterprise characteristics. The company's internal financial and governance structure will also affect the enterprise's ability to fulfill social responsibility. Internal financial aspects, the economic ability and financial situation of the enterprise all affect the ability of the enterprise to implement social responsibility $[12,13]$. The better the economic capacity and financial status of the enterprise, the sparer resources it will be able to allocate to socially responsible activities [14]. In terms of governance structure, executive shareholding $[15,16]$, political affiliation [17] and so on all have an impact on corporate social responsibility.

\subsection{Executives' Characteristics and Corporate Social Responsibility}

The practice of corporate social responsibility is reflected in the organizational level of enterprises. However, the fulfillment of corporate social responsibility requires capital expenditure, so it relies on senior executives to make decisions. Therefore, to some extent, the commitment and participation of senior executives indicate the performance of corporate social responsibility $[18,19]$. At present, some scholars have studied the influence of executives' background characteristics on corporate social responsibility from the perspective of entrepreneurs' values and thinking patterns. Some empirical research found that entrepreneurs' personalities, values and ways of thinking influence their attitudes towards corporate social responsibility. Specifically, the age of senior executives will affect the performance of corporate social responsibility. With the increase in senior executives' age, they are more willing to make formal and routine decisions, rather than challenge the existing formal or informal industrial and organizational structure, which will reduce the possibility of illegal corporate behaviors [20]. The 
tenure of senior executives will affect the fulfillment of corporate social responsibility. The longer the tenure, the more executives understand the scope of the needs of corporate stakeholders, the more they can build a good relationship network, and the more they can view corporate social responsibility from a long-term perspective, for example, the tenure of hospital managers is positively related to the relationship between local business associations and other organizations. The professional experience of senior executives will affect the fulfillment of corporate social responsibility. The cognition and preference of managers are partly derived from the experience accumulated in their career; therefore, they tend to have the orientation of professional experience in their work, which will affect their perception of the environment [3]. The compensation of senior executives will affect the fulfillment of corporate social responsibility, for example, Deckop (2006) [21] explored the relationship between a CEO's compensation structure and corporate social responsibility and found that the CEO's compensation structure is negatively correlated with corporate social responsibility in the short term, while positively correlated in the long term.

The gender of senior executives will affect the fulfillment of corporate social responsibility. Many scholars have revealed the relationship between female senior executives and corporate social responsibility through empirical analysis, providing new theoretical support and paths for further improving the fulfillment of corporate social responsibility and promoting gender equality. In addition, the age heterogeneity of the executive team, the heterogeneity of tenure, the heterogeneity of professional experience and so on will also have a certain impact on corporate social responsibility [18, 22].

Based on the comprehensive analysis of the existing domestic and foreign literature, the lack of research on executive background and corporate social responsibility is mainly reflected by the following aspects: (1) Corporate social responsibility performance is measured mainly through the ranking of various responsibility rating websites and other intermediary agencies, or by issuing questionnaires and conducting statistical analysis of the questionnaire results. Due to the inadequacy of the rating model and the reliability of the questionnaire, the data or conclusions are not objective to some extent. (2) Although the background characteristics of senior executives have attracted the attention of the academic circle, the research on the influential factors of corporate social responsibility based on the background characteristics of senior executives is still relatively limited [23]; there is even less research on how the education of senior executives influences the fulfillment of corporate social responsibility. (3) The existing research mainly focuses on the correlation between a certain background characteristic of an executive and the performance of corporate social responsibility, while studies on the influential mechanism of executive background characteristics related to corporate social responsibility performance are scarce, that is, researchers do not seem to attach importance to the exploration of the intermediate medium of the two. (4) Most empirical studies use the ordinary least square method, which is relatively simple, but cannot eliminate the non-observational heterogeneity that does not change with time.

With the deepening of economic globalization, highly educated senior executives have become an important subject that cannot be ignored in the capital market. As an important background feature of senior executives, educational background will affect their cognitive ability and values to a certain extent, and will ultimately affect the decision-making of enterprises. However, to date, research has not paid attention to the influence of the educational background of senior executives on the fulfillment of enterprises' social responsibilities. In view of this, this paper, based on the "Upper Echelon Perspective", discusses the impact of an executive's level of education on corporate social responsibility, and verifies the positive impact of the executive's level of education on corporate social responsibility from the perspective of theory and experience. We also introduce a CEO who also chairs the board, a CEO in state-owned enterprises, and a CEO with overseas experience as moderator variables to further explore and prove the influence of an executive's level of education on corporate social responsibility performance.

The contributions of this paper are highlighted in the following aspects: First, theoretically, there are few studies on the influence of executive education on corporate social responsibility at domestic and foreign levels. This paper provides a new idea to explore the relationship between an executive's level of education and corporate social responsibility. Our research enriches the existing academic literature on the influence of executive background characteristics on corporate social responsibility. Second, considering the characteristics of China, we have conducted a detailed heterogeneous study on the impact of the CEO's level of education on CSR.

This paper is organized as follows: the second part is a theoretical analysis and research hypothesis; the third part includes the data and an econometric model; the fourth part shows the empirical results analysis; and the fifth part presents the conclusions and enlightenment.

\section{Theoretical Analysis and Research Assumptions}

This paper follows the hypothesis of finite rationality and studies it based on the "Upper Echelon Perspective". The Upper Echelon Perspective states that the cognition of managers towards external things is a gradual process: First, the vision of managers is limited. It is impossible for them to thoroughly examine all aspects of the internal and external environment of the enterprise. Second, even for those phenomena in their field of vision, the managers will only make selective observations. Finally, managers' different cognitive bases, values, insights and the process of these characteristics will make the information processing and 
filtering selective, thus forming different strategic choices. Although cognitive basis, values, insight and other characteristics have strong explanatory power for executive behaviors, they are difficult to measure in empirical studies because they belong to the psychological dimension. Therefore, Hambrick \& Mason (1984) [24] further enriched the "Upper Echelon Perspective" and divided the characteristics of executives into psychological characteristics and demographic background characteristics. Demographic background characteristics are a projection index of psychological characteristics, which can effectively explain psychological factors such as cognitive basis, values and insight. That is, demographic background characteristics can be used as proxy variables for trait variables such as cognitive basis, values and insight. At the same time, demography has the advantages of being objective, simple, easy to understand, logically consistent, able to make predictions and easy to measure. Therefore, the academic circle often uses the demographic indicators of managers for indirect measurement, including age, education background, professional experience, socio-economic background, team heterogeneity, etc.

The core view of the "Upper Echelon Perspective" is that the demographic background characteristics of executives will affect the strategic choice and decision-making of enterprises, so many scholars choose the demographic background characteristics of entrepreneurs to explore the corporate strategy.

However, the form of corporate social responsibility information disclosure, what content to disclose, and whether to hire a third party to examine are undoubtedly decisions to be taken by the enterprise, so corporate social responsibility information disclosure is bound to be affected by the background characteristics of executives. To date, many scholars have verified the correlation between the background characteristics of the executive population and the disclosure of corporate social responsibility information through empirical research (Jia Ming, 2010). For example, some scholars confirm that female executives have a stronger sense of social responsibility than men, and that corporate social responsibility information disclosure, which has a high proportion of female executives, is of higher quality. Thomas andSimerly (1995) [25] found that executive professional background was significantly correlated with social responsibility information disclosure, and that this correlation was regulated by industry type. Researchers also studied the correlation between corporate governance structure and social responsibility information disclosure and found that the average education level of executives is significantly positively correlated with social responsibility information disclosure, while there is no significant correlation between average age and social responsibility information disclosure. Empirical studies showthat there is a significantly positive correlation between the age, education level, social reputation and social responsibility information disclosure of the executive team, and this correlation is different between private corporates and state-owned corporates.

According to the above analysis, the effective implementation of corporate social responsibility as a corporate strategy will also be affected by the characteristics of executives. In the study of corporate social responsibility based on the "Upper Echelon Perspective", most scholars chose variables such as age, gender and professional background (tenure, function, etc.) to measure the demographic characteristics of entrepreneurs [26]. However, there is a relative lack of research on how an executive's level of education influences the implementation of corporate social responsibility. In addition, most domestic scholars focus on the overall collaborative research of the entire executive team, and there is little clear research on individual entrepreneurs and managers. Therefore, this paper intends to explore the internal motivation for the effective performance of corporate social responsibility through the background feature of the executive's level of education.

Education is an important characteristic of executives. The process of learning for the individual is a very important life experience; a person's education level will have a profound impact on their cognitive basis, values, insight and other characteristics. The educational background of senior executives is closely related to their cognitive ability, learning ability, receptivity and innovation ability, which will directly affect their ability to make correct decisions in the face of a complex and changeable environment. According to the "Upper Echelon Perspective", the education level of executives will have an impact on their cognitive basis, values and insight and will then affect the strategic decisions and performance of enterprises. Specifically, in the area of corporate social responsibility, executives' education may influence their perceptions and values of social responsibility, which in turn affect the social responsibility practices of their enterprises.

On the one hand, highly educated executives will identify more with the concept and thinking of corporate social responsibility. Generally speaking, highly educated executives can think more rationally and identify opportunities and challenges. In the current economic situation, they can consider the demands of all stakeholders and maintain balanced economic, environmental and social development. On the other hand, the higher the educational level of senior executives, the higher their economic status is generally. They tend to pursue more than profit and income and pay more attention to social livelihood and the ecological environment. Based on the above analysis and discussion, this paper puts forward the following hypothesis.

Hypothesis 1 (H1). The CEO's level of education is positively correlated with CSR.

Generally speaking, in economic organizations, a CEO is responsible for the daily affairs of an enterprise. He or she has the ultimate executive power within the company or organization. The CEO is responsible to the board of directors of the company and is often a member of the board of directors. On the other hand, the chairman of the board of directors of the company is the company's supreme leader. A chairman has administrative power and manages the company's specific business. The chairman has the highest power among the 
board and is able to remove the CEO. However, in many enterprises, the CEO often serves as the chairman of the board. Such a duality may affect the CEO`s behavior. In more detail, when the CEO is also the chairman of the board, the CEO will have a greater role and more power, so their cognition and value placed on social responsibility will have more influence on the social responsibility practice of the company [27]. Based on the above analysis and discussion, this paper puts forward the following hypothesis.

Hypothesis $2 \mathrm{a}(\mathrm{H} 2 \mathrm{a})$. Comparing with companies where $C E O$ and chairman are separated, for companies where the $C E O$ is also the chairman of the board of directors, the CEO's level of education has a more positive effect on CSR.

For state-owned corporates, the decision-making process to achieve the desired political image and profit goals is often complex and often gives priority to political goals. In general, as the executives of state-owned corporates usually have administrative responsibilities, the rise or fall of an enterprise's image will negatively or positively affect their official image, which, in turn, will affect their chances of promotion. Therefore, the state-owned corporates face more political pressure and public concern than non-state-owned corporates. Consequently, the CEO of state-owned corporates pays more attention to corporate social responsibility to achieve effective performance. The executives of non-state-owned corporates pay more attention to how to maximize profits and will consider corporate social responsibility from an economic perspective. Corporate social responsibility will only be considered if the expected benefits of corporate social responsibility outweigh its costs, or if the market environment requires it. Therefore, companies with different property right structures have completely different motivations to fulfill corporate social responsibility [28, 29]. Based on the above analysis and discussion, this paper puts forward the following hypothesis.

Hypothesis $2 \mathrm{~b}(\mathrm{H} 2 \mathrm{~b})$. Among state-owned corporates, the CEO's level of education plays a more positive role than non-state-owned corporates in promoting CSR.

The concept of corporate social responsibility was introduced in China in the 1990s, so the general level of public awareness of corporate social responsibility is relatively low. In China's talent training system, corporate social responsibility education is relatively absent. Senior executives with overseas backgrounds have been educated and influenced by overseas culture for a long time and have personal experience in the practice of social responsibility of overseas enterprises. Relative to home-grown executives, executives with an overseas background in terms of social responsibility have strong consciousness and conception. When corporates are faced with strategic choices, these types of executives, based on their own cognition and values, are more capable of leading corporates to be in line with international standards in terms of corporate social responsibility and to promote corporates to actively fulfill their social responsibilities. Based on the above analysis and discussion, this paper puts forward the following hypothesis.

Hypothesis 2c $(\mathrm{H} 2 \mathrm{c})$. Compared with companies whose
CEOs have no overseas experience, for companies whose CEO has an overseas experience, the CEO's level of education has a greater positive effect on the CSR.

\section{Data and Econometric Model}

\subsection{Research Samples and Data Sources}

This paper selected Chinese A-share listed companies from 2008 to 2015 as the initial sample for research. The CSR performance, data on CEOs' characteristics and firms' characteristics were obtained from the CSMAR database. Drawing on the practice of existing research, this paper removed the following companies: (1) ST listed companies; (2) financial, insurance, real estate listed companies; and (3) companies with missing data on related variables. In order to eliminate the influence of extreme values, the continuous variables used in this paper are all truncated at the levels of $1 \%$ and 99\%. Finally, 13, 761 observations were obtained.

\subsubsection{The Measurement of the CSR}

The measurement methods of corporate social responsibility in the literature usually include the index method and content analysis method. The index method firstly classifies corporate social responsibility and then scores and summarizes corporate social responsibility according to both qualitative and quantitative dimensions. The content analysis method scores corporate social responsibility according to the content related to social responsibility in corporate reports. Existing literature [30] combines the two methods to score corporate social responsibility disclosure. In view of this, this paper selected two proxy variables, CSR Score and CSR Disclosure, to measure the CSR of A-share listed companies. According to the disclosure of CSR in the annual reports of listed companies in China, we set a dummy variable CSR Disclosure to measure the CSR performance of a firm. In addition, the performance of CSR is divided into seven dimensions, namely, Staff protection, Delivery protection, Customer protection, Environment protection, Public relations, System construction and Work safety. Seven dummy variables are set for the disclosure of each dimension. We define the summation of the disclosure of seven sub-CSR items as a variable CSR Score to measure the comprehensive situation of corporate social responsibility of A-share listed companies.

\subsubsection{Measurement of Explanatory Variables}

The main explanatory variable of this paper is the executive's level of education (ceo_degree), which is obtained from the CSMAR database. In order to intuitively understand the impact of the executive's level of education on CSR performance, in this paper, the CEO's level of education is divided into six different levels: $1=$ Secondary and below Secondary schools, 2 = Junior College, $3=$ Undergraduate, $4=$ Master, $5=$ Doctor.

\subsubsection{Measurement of Control Variables}

According to the relevant literature, we set several control 
variables from the aspects of CEO characteristics and firm characteristics. The characteristics of the CEO include the age of the CEO (ceo age); the overseas experience of the CEO (ceo_oversea), the gender of the CEO (ceo_female) and the tenure of the CEO (ceo_tenure). The characteristics of the firm include size (logarithm of total assets, lnat), return on assets (roa), market to book ratio ( $m t b)$, leverage (leverage), ownership concentration (Herfindahl Index of shareholding proportion of the top-10 shareholders, shrffd10), and state ownership (soe). The definition and measurement of specific variables are shown in Appendix, Table 7.

\subsection{Model Setting}

In order to explore the relationship between the executive's level of education and the corporate social responsibility performance, the following regression model was constructed:

$$
\begin{gathered}
C S R_{i, t}=\beta_{0}+\beta_{1} \text { ceo_degree }_{i, t-1}+\beta_{2} C_{i, t-1}+\beta_{3} F_{i, t-1}+\phi_{i} \\
+\phi_{t}+\varepsilon_{i, t}
\end{gathered}
$$

The subscripts $i$ and $t$ refer to the corporation and year, respectively; $C S R_{i, t}$ is the corporate social responsibility performance of corporate $i$ in year $t$. In this paper, CSR Score and CSR Disclosure were selected as two proxy variables; ceo_degree $e_{i, t-1}$ is the educational background of the CEO of enterprise $i$ in year $t-1 ; C_{i, t-1}$ and $F_{i, t-1}$ represent the basic characteristics of the $\mathrm{CEO}$ and the fundamental characteristics of corporate $i$ in year $t-1 ; \phi_{i}$ and $\phi_{t}$ are industry and year fixed effect, respectively; $\varepsilon_{i, t}$ is the residual term.

The characteristics of the CEO include the age of the CEO (ceo_age), the overseas experience of the CEO (ceo_oversea), the gender of the CEO (ceo_female) and the tenure of the CEO (ceo_tenure). The characteristics of the firm include size (logarithm of total assets, lnat), return on assets (roa), market to book ratio ( $m t b)$, leverage (leverage), ownership concentration (Herfindahl Index of shareholding proportion of the top-10 shareholders, shrffd10), and state ownership (soe). The definition and measurement of specific variables are shown in Appendix, Table 7.

\section{Empirical Results}

\subsection{Descriptive Statistics and Univariate Test}

Table 1 reports descriptive statistics for major variables. The mean value of the CSR Disclosure variables was 0.227 , and the standard deviation was 0.419 . The mean value of the CSR Score variables was only 1.298, and the standard deviation was 2.437 . This shows that the overall situation of sample enterprises' CSR performance in China is not that good, and there are large differences in CSR performance among different enterprises. Specifically, the seven dimensions of the CSR Score are as follows. Among them, the mean value of the Staff protection variable is the largest (0.226), while the mean value of the System construction variable is the smallest (0.0593). In addition, the standard deviation of the seven dimensions is large. This shows that, relatively speaking, sample enterprises pay more attention to Staff protection's CSR, but most of them neglect to fulfill their CSR in System construction. At the same time, the mean value of the variable ceo_degree is 3.3980, and the standard deviation of the variable ceo_degree is 0.911 . This indicates that most CEOs in the sample companies have bachelor's degrees.

\begin{tabular}{|c|c|c|c|c|c|c|}
\hline \multicolumn{7}{|c|}{ Panel A: CSR Performance } \\
\hline & $\mathbf{N}$ & Mean & p25 & p50 & p75 & S.D. \\
\hline CSR Score & 13,761 & 1.298 & 0 & 0 & 0 & 2.437 \\
\hline CSR Disclosure & 13,761 & 0.227 & 0 & 0 & 0 & 0.419 \\
\hline Delivery protection & 13,761 & 0.168 & 0 & 0 & 0 & 0.374 \\
\hline Customer protection & 13,761 & 0.217 & 0 & 0 & 0 & 0.412 \\
\hline Environment protection & 13,761 & 0.222 & 0 & 0 & 0 & 0.415 \\
\hline Public relations & 13,761 & 0.219 & 0 & 0 & 0 & 0.414 \\
\hline System construction & 13,761 & 0.0593 & 0 & 0 & 0 & 0.236 \\
\hline Work safety & 13,761 & 0.186 & 0 & 0 & 0 & 0.389 \\
\hline \multicolumn{7}{|c|}{ Panel B: CEO Characteristics } \\
\hline & $\mathrm{N}$ & Mean & $\mathrm{p} 25$ & $\mathrm{p} 50$ & p75 & S.D. \\
\hline ceo_ago & 13,761 & 51.86 & 47 & 51 & 56 & 7.082 \\
\hline ceo_degree & 13,761 & 3.3980 & 3 & 4 & 4 & 0.911 \\
\hline ceo_overseas & 13,761 & 0.0664 & 0 & 0 & 0 & 0.249 \\
\hline ceo_female & 13,761 & 0.0430 & 0 & 0 & 0 & 0.203 \\
\hline \multicolumn{7}{|c|}{ Panel C: Firm Characteristics } \\
\hline & $\mathrm{N}$ & Mean & $\mathrm{p} 25$ & p50 & p75 & S.D. \\
\hline lnat & 13,761 & 21.83 & 20.91 & 21.64 & 22.54 & 1.290 \\
\hline roa & 13,761 & 0.0399 & 0.0143 & 0.0385 & 0.0676 & 0.0570 \\
\hline$m t b$ & 13,761 & 4.029 & 1.876 & 2.899 & 4.750 & 4.072 \\
\hline leverage & 13,761 & 0.431 & 0.252 & 0.424 & 0.601 & 0.224 \\
\hline shrhfd10 & 13,761 & 0.172 & 0.0787 & 0.144 & 0.239 & 0.120 \\
\hline soe & 13,620 & 0.366 & 0 & 0 & 1 & 0.482 \\
\hline
\end{tabular}

Table 1. Data Description. 
Table 2 reports the results of the univariate test. In order to better understand the influence of executive education on corporate CSR decision-making, this paper grouped the observed values according to the five levels of ceo_degree, and compared the average CSR Score and CSR Disclosure of each group. G1-G5 corresponds to the CEO's level of education from 1 to 5, so the G5 group has the highest level of education. It can be seen that the mean values of the CSR Score and CSR Disclosure of the G5 group were significantly higher than those of the G1 group, and the univariate analysis results intuitively supported our hypothesis that executive education does have a significantly positive impact on CSR performance.

Table 2. Univariate analysis, the CEO's level of education and CSR performance.

\begin{tabular}{llll}
\hline Group & N & Mean Value of CSR Score & Mean Value of CSR Disclosure \\
\hline G1 & 419 & 0.8807 & 0.1459 \\
G2 & 1817 & 0.8162 & 0.1420 \\
G3 & 4381 & 1.1144 & 0.1958 \\
G4 & 6158 & 1.4711 & 0.2580 \\
G5 & 986 & 2.0943 & 0.3651 \\
G5-G1 $(p$-value) & & $1.2137^{* * *(0.0000)}$ & $0.2195^{* * *}(0.0000)$ \\
\hline
\end{tabular}

Notes: $p$-values are presented in parentheses; *** $p<0.01, * * p<0.05, * p<0.1$.

\subsection{Benchmark Regression Analysis}

Table 3 reports the regression analysis results of the effect of the executive's level of education on CSR performance. Models (1) and (2) are OLS and Poisson regression results, respectively, when the dependent variable is the CSR Score. In models (1) and (2), the regression coefficient of the independent variable ceo_degree are 0.1630 and 0.1072 , respectively. Both results are significant at the $1 \%$ level. This shows that the CEO's level of education is positively correlated with the fulfillment of corporate social responsibility. Models (3) and (4) are the respective OLS and Poisson regression results when the dependent variable is CSR Disclosure. In models (3) and (4), the regression coefficient of the independent variable ceo_degree are 0.1075 and 0.1886 , respectively, and both results are significant at the $1 \%$ level, which again provided supporting evidence for hypothesis H1. This verifies the basic conclusion: the CEO's level of education is positively correlated with the fulfillment of corporate social responsibility.

Among the control variables, the regression coefficients of lnat, roa and soe in all dimensions were significantly positive. This shows that larger firms, with higher profitability, high growth opportunity and state ownership, have better CSR performance.

We also found that the regression coefficients of ceo female, leverage and shrhfd10 in all dimensions are significantly negative. This means that female CEOs, firms with a high leverage ratio and higher ownership concentration, have worse CSR performance.

Table 3. CEO's level of education and CSR performance.

\begin{tabular}{|c|c|c|c|c|}
\hline & \multicolumn{2}{|l|}{ CSR Score } & \multicolumn{2}{|l|}{ CSR Disclosure } \\
\hline & (1) & (2) & (3) & (4) \\
\hline & OLS & Poisson & Probit & Logistic \\
\hline ceo_degree & $0.1630 * * *(0.0246)$ & $0.1072 * * *(0.0195)$ & $0.1075 * * *(0.0178)$ & $0.1886 * * *(0.0317)$ \\
\hline ceo_age & $0.0053 *(0.0031)$ & $0.0027(0.0025)$ & $0.0033(0.0022)$ & $0.0048(0.0039)$ \\
\hline ceo_female & $-0.3188 * * *(0.0904)$ & $-0.2837 * * *(0.0969)$ & $-0.1890 * *(0.0759)$ & $-0.3290 * *(0.1343)$ \\
\hline ceo_tenure & $0.0015 *(0.0008)$ & $0.0007(0.0005)$ & $0.0012 * *(0.0005)$ & $0.0022 * *(0.0009)$ \\
\hline ceo_oversea & $0.0823(0.0887)$ & $0.0497(0.0626)$ & $0.0453(0.0613)$ & $0.0626(0.1083)$ \\
\hline Roa & $2.7536 * * *(0.4004)$ & $3.6832 * * *(0.3642)$ & $2.5902 * * *(0.3515)$ & $4.7397 * * *(0.6225)$ \\
\hline Mtb & $0.0434 * * *(0.0057)$ & $0.0106 *(0.0063)$ & $0.0269 * * *(0.0053)$ & $0.0503 * * *(0.0093)$ \\
\hline Leverage & $-0.6245 * * *(0.1219)$ & $-0.1891 *(0.1063)$ & $-0.4705 * * *(0.1022)$ & $-0.8821 * * *(0.1781)$ \\
\hline shrhfd 10 & $-0.8607 * * *(0.1948)$ & $-0.8697 * * *(0.1265)$ & $-0.6314 * * *(0.1280)$ & $-1.1618 * * *(0.2247)$ \\
\hline Soe & $0.3613 * * *(0.0525)$ & $0.2712 * * *(0.0378)$ & $0.2516 * * *(0.0336)$ & $0.4359 * * *(0.0588)$ \\
\hline Constant & $-20.1198 * * *(0.4730)$ & $-11.7486 * * *(0.3094)$ & $-14.6255 * * *(0.4021)$ & $-25.7473 * * *(0.7266)$ \\
\hline Year FE & YES & YES & YES & YES \\
\hline Observations & 11,305 & 11,305 & 11,304 & 11,304 \\
\hline $\mathrm{R} 2$ & 0.236 & 0.186 & 0.231 & 0.233 \\
\hline
\end{tabular}

Notes: Robust standard errors are presented in parentheses; $* * * p<0.01, * * p<0.05, * p<0.1$.

\subsection{Robustness Test}

\subsubsection{CEO's Level of Education and CSR Sub-performance}

In order to further investigate the influence of the executive's level of education on indicators of different dimensions of corporate social responsibility, this paper uses seven sub-dimensional indicators to test the basic model, and the results are shown in Appendix, Table 8. We replace the dependent variable with the sub-item of the CSR score. It can be seen that, except for System construction, there is a 
significantly positive correlation between the CEO's level of education and each sub-item score.

The variable ceo_age has a significantly positive correlation with Delivery protection, Customer protection and Work safety, which are sub-items of the CSR score. The variable ceo tenure was positively correlated with Staff protection, Environment protection and Public relations of the sub-project scored in CSR. The variable $m t b$ has a significantly positive correlation with the scores of all the sub-items, except System construction. The variables lnat, roa and soe have significantly positive correlations with all sub-items of the CSR score. The variable ceo_oversea only has a significantly positive correlation with Work safety, which is a sub-item of the CSR score. However, the variables ceo_female and leverage have significantly negative correlations with all the sub-item of the CSR score except System construction. shrhfd10 have a significantly negative correlation with all sub-items of the CSR score. These empirical results are mostly consistent with the conclusion of the basic model, proving the robustness of the basic model.

\subsubsection{CEO's Level of Education and CSR Forward Performance}

In Appendix, Table 9, we replace the dependent variable with the average CSR Score of the enterprise in the next three years. It can be seen from models (1) and (2) that when the dependent variable is the forward 3-year average value of the CSR Score, the regression coefficients of the independent variable ceo_degree are 0.1560 and 0.0872 , respectively, and both are significant at the $1 \%$ level. This shows that the CEO's level of education is positively correlated with the fulfillment of corporate social responsibility in the future. Models (3) and (4) used the forward 3-year average value of CSR Disclosure as the dependent variable, and the regression coefficients of the independent variable ceo_degree are 0.0842 and 0.1451 , respectively, and both are significant at the $1 \%$ level. Compared with the empirical results of the basic model, the results in Table 9 in Appendix show that the regression coefficients of ceo_degree in models (1)-(4) all decrease, but they are still significantly positive, which verifies the basic conclusion: the CEO's level of education is positively correlated with the fulfillment of corporate social responsibility. The robustness of the model is proved again.

\subsection{Expansion Analysis}

\subsubsection{Impact of CEO Duality}

Table 4 presents the results of the moderating effect $(\mathrm{H} 2 \mathrm{a})$ of CEO duality on the CEO's level of education and corporate social responsibility. We define duality as a dummy variable in which the CEO also serves as the chairman. When the CEO is also the chairman, duality $=1$; otherwise, duality $=0$. We add duality and the interaction between duality and ceo_degree into the basic regression model. It can be seen that the results of the interaction item are significantly positive, indicating that the CEO concurrently serving as the chairman can improve the influence of the CEO's level of education on the CSR performance of the enterprise. This is because when CEOs are also the chairman of the board, they will have a greater role and more power, so their cognition and value placed on social responsibility will have a greater impact on the practice of social responsibility of the company they work for. Therefore, when the CEO is also the chairman of the board of directors, the CEO's level of education has a strong positive effect on the fulfillment of social responsibility.

Table 4. CEO Duality.

\begin{tabular}{|c|c|c|c|c|}
\hline & \multicolumn{2}{|l|}{ CSR Score } & \multicolumn{2}{|l|}{ CSR Disclosure } \\
\hline & (1) & (2) & (3) & (4) \\
\hline & OLS & Poisson & Probit & Logistic \\
\hline ceo_degree & $0.1378 * * *(0.0298)$ & $0.0784 * * *(0.0213)$ & $0.0823 * * *(0.0203)$ & $0.1434 * * *(0.0358)$ \\
\hline duality & $-0.4111 * *(0.1605)$ & $-0.7613 * * *(0.1877)$ & $-0.5255 * * *(0.1459)$ & $-0.9156 * * *(0.2640)$ \\
\hline ceo_degree*duality & $0.0861 *(0.0481)$ & $0.1650 * * *(0.0486)$ & $0.1169 * * *(0.0406)$ & $0.2094 * * *(0.0728)$ \\
\hline ceo_age & $0.0044(0.0031)$ & $0.0016(0.0025)$ & $0.0025(0.0022)$ & $0.0036(0.0039)$ \\
\hline ceo_female & $-0.3215 * * *(0.0905)$ & $-0.2776 * * *(0.0970)$ & $-0.1898 * *(0.0758)$ & $-0.3261 * *(0.1343)$ \\
\hline ceo_oversea & $0.0873(0.0889)$ & $0.0550(0.0627)$ & $0.0474(0.0613)$ & $0.0702(0.1081)$ \\
\hline lnat & $0.9366 * * *(0.0232)$ & $0.4949 * * *(0.0141)$ & $0.5951 * * *(0.0190)$ & $1.0462 * * *(0.0337)$ \\
\hline roa & $2.8040 * * *(0.4048)$ & $3.6178 * * *(0.3656)$ & $2.5860 * * *(0.3552)$ & $4.7194 * * *(0.6255)$ \\
\hline $\mathrm{mtb}$ & $0.0443 * * *(0.0058)$ & $0.0117 *(0.0062)$ & $0.0278 * * *(0.0053)$ & $0.0516 * * *(0.0093)$ \\
\hline leverage & $-0.6645 * * *(0.1235)$ & $-0.2316 * *(0.1074)$ & $-0.5030 * * *(0.1037)$ & $-0.9310 * * *(0.1797)$ \\
\hline shrhfd10 & $-0.8631 * * *(0.1961)$ & $-0.8496 * * *(0.1278)$ & $-0.6228 * * *(0.1290)$ & $-1.1501 * * *(0.2266)$ \\
\hline soe & $0.3542 * * *(0.0537)$ & $0.2567 * * *(0.0381)$ & $0.2432 * * *(0.0343)$ & $0.4270 * * *(0.0599)$ \\
\hline Industry FE & YES & YES & YES & YES \\
\hline Observations & 11,209 & 11,209 & 11,208 & 11,208 \\
\hline $\mathrm{R} 2$ & 0.236 & 0.187 & 0.232 & 0.234 \\
\hline
\end{tabular}

Notes: Robust standard errors are presented in parentheses; $* * * p<0.01, * * p<0.05, * p<0.1$.

\subsubsection{Impact of State Ownership}

Table 5 shows the results of the moderating effect $(\mathrm{H} 2 \mathrm{~b})$ of state-owned corporates on the relationship between the CEO's level of education and corporate social responsibility. Based on the basic model, this paper defines the dummy variable of whether a corporate is a state-owned enterprise. When a corporate is a state-owned enterprise, soe $=1$, otherwise soe $=$ 
0 . We add the interaction term of soe and ceo_degree into the basic regression model. It can be seen that the results of the interaction term are significantly positive, indicating that the CEO's level of education has a more significant effect on the improvement of CSR performance in state-owned enterprises than those in non-state-owned enterprises.

An explanation for this result is that corporates with different property right structures have completely different motivations to fulfill their CSR. For non-state-owned enterprises, their executives will pay more attention to how to achieve profit maximization and will consider corporate social responsibility from an economic perspective. They will only consider corporate social responsibility when the expected return of undertaking it outweighs its cost, or when the market environment requires it. By contrast, in state-owned enterprises, in general, the decision-making process to achieve the desired political image and profit goals is often complex and often gives priority to political objectives. As the executives of state-owned enterprises usually have administrative responsibilities, the rise or fall of an enterprise's image will negatively or positively affect their official image which, in turn, will affect their chances of promotion. Therefore, the state-owned corporates face more political pressure and public concern than non-state-owned corporates. Consequently, CEOs of state-owned corporates pay more attention to corporate social responsibility to achieve effective performance. Therefore, among state-owned corporates, the CEO's level of education plays a more positive role in promoting enterprises to fulfill their social responsibilities.

Table 5. State Ownership.

\begin{tabular}{|c|c|c|c|c|}
\hline & \multicolumn{2}{|l|}{ CSR Score } & \multicolumn{2}{|l|}{ CSR Disclosure } \\
\hline & (1) & $(2)$ & (3) & (4) \\
\hline & OLS & Poisson & Probit & Logistic \\
\hline ceo_degree & $0.1038 * * *(0.0275)$ & $0.0996 * * *(0.0268)$ & $0.0763 * * *(0.0211)$ & $0.1350 * * *(0.0375)$ \\
\hline soe & $-0.4094 * *(0.2063)$ & $0.2071(0.1393)$ & $-0.1016(0.1374)$ & $-0.1451(0.2435)$ \\
\hline ceo_degree*soe & $0.2206 * * *(0.0575)$ & $0.0181(0.0377)$ & $0.1004 * * *(0.0377)$ & $0.1646 * *(0.0667)$ \\
\hline ceo_age & $0.0057 *(0.0031)$ & $0.0028(0.0025)$ & $0.0035(0.0022)$ & $0.0051(0.0039)$ \\
\hline ceo_female & $-0.2965 * * *(0.0906)$ & $-0.2812 * * *(0.0971)$ & $-0.1768 * *(0.0759)$ & $-0.3074 * *(0.1345)$ \\
\hline ceo_oversea & $0.0827(0.0883)$ & $0.0502(0.0626)$ & $0.0448(0.0614)$ & $0.0642(0.1086)$ \\
\hline lnat & $0.9325 * * *(0.0231)$ & $0.4986 * * *(0.0141)$ & $0.5961 * * *(0.0189)$ & $1.0509 * * *(0.0335)$ \\
\hline roa & $2.8117 * * *(0.4001)$ & $3.6887 * * *(0.3647)$ & $2.6198 * * *(0.3517)$ & $4.7884 * * *(0.6241)$ \\
\hline $\mathrm{mtb}$ & $0.0439 * * *(0.0057)$ & $0.0107 *(0.0063)$ & $0.0272 * * *(0.0053)$ & $0.0509 * * *(0.0093)$ \\
\hline leverage & $-0.6076 * * *(0.1221)$ & $-0.1873 *(0.1065)$ & $-0.4666 * * *(0.1022)$ & $-0.8725 * * *(0.1784)$ \\
\hline shrhfd10 & $-0.9206 * * *(0.1955)$ & $-0.8762 * * *(0.1274)$ & $-0.6568 * * *(0.1287)$ & $-1.1989 * * *(0.2258)$ \\
\hline Constant & $-19.8268 * * *(0.4811)$ & $-11.7145 * * *(0.3198)$ & $-14.4992 * * *(0.4054)$ & $-25.5339 * * *(0.7314)$ \\
\hline Industry FE & YES & YES & YES & YES \\
\hline Observations & 11,305 & 11,305 & 11,304 & 11,304 \\
\hline $\mathrm{R} 2$ & 0.237 & 0.186 & 0.232 & 0.234 \\
\hline
\end{tabular}

Notes: Robust standard errors are presented in parentheses; $* * * p<0.01, * * p<0.05, * p<0.1$.

\subsubsection{Impact of the CEO's Overseas Experience}

Table 6 shows the results of the moderating effect $(\mathrm{H} 2 \mathrm{c})$ of the CEO's overseas experience on the relationship between CEO's level of education and corporate social responsibility. In the basic model, this paper defines the dummy variable ceo_oversea as the overseas experience of the CEO. When the CEO has studied or worked abroad, ceo_oversea $=1$; otherwise, ceo_oversea $=0$. We add the interaction item of ceo_oversea and ceo_degree to the basic regression model. As can be seen, the results of the interaction item are significantly positive, indicating that the level of education of CEOs with overseas experience has a more significant effect on the improvement of CSR performance than firms whose CEOs have no overseas experience.

This is because, on the one hand, compared with foreign countries, China's social responsibility education is relatively underdeveloped. CEOs with overseas experience are more likely to accept the values of social responsibility and put them into practice. Executives with overseas experience know more about the advanced overseas experience in the field of corporate social responsibility, are more familiar with overseas enterprises' operation pattern and the way in which corporate social responsibility is practiced, are better able to apply overseas enterprises' advanced management ideas and values in China, and promote the company's corporate social responsibility performance. Therefore, compared to CEOs who stay in China, executives with overseas experience in the aspect of social responsibility have a strong consciousness and conception when enterprises face a strategic choice. Based on their own cognition, executives with overseas experience and values work more in line with international standards in terms of corporate social responsibility and promote the enterprises to actively fulfill their social responsibility. Therefore, when the CEO has studied or worked overseas, the CEO's level of education has a greater positive effect on the fulfillment of social responsibility than those who do not have overseas experience. 
Table 6. State Ownership.

\begin{tabular}{lllll}
\hline & CSR Score & & CSR Disclosure & \\
\cline { 2 - 5 } & $\mathbf{( 1 )}$ & $\mathbf{( 2 )}$ & $\mathbf{3})$ & $\mathbf{( 4 )}$ \\
\cline { 2 - 5 } & OLS & Poisson & Probit & Logistic \\
\hline ceo_degree & $0.1430 * * *(0.0255)$ & $0.0887 * * *(0.0201)$ & $0.0914 * * *(0.0184)$ & $0.1635 * * *(0.0327)$ \\
ceo_oversea & $-1.0502 * * *(0.2908)$ & $-1.1545 * * *(0.3037)$ & $-1.0773 * *(0.2896)$ & $-1.6571 * * *(0.5136)$ \\
ceo_degree*ceo_oversea & $0.2985 * * *(0.0827)$ & $0.2951 * * *(0.0711)$ & $0.2831 * * *(0.0729)$ & $0.4334 * * *(0.1287)$ \\
ceo_age & $0.0048(0.0031)$ & $0.0021(0.0025)$ & $0.0027(0.0022)$ & $0.0040(0.0039)$ \\
ceo_female & $-0.3219 * * *(0.0903)$ & $-0.2818 * * *(0.0969)$ & $-0.1879 * *(0.0759)$ & $-0.3278 * *(0.1344)$ \\
ceo_tenure & $0.0016^{* * *}(0.0008)$ & $0.0008 *(0.0005)$ & $0.0012 * *(0.0005)$ & $0.0023 * *(0.0009)$ \\
lnat & $0.9377 * * *(0.0230)$ & $0.4992 * * *(0.0140)$ & $0.5983 * * *(0.0189)$ & $1.0531 * * *(0.0335)$ \\
roa & $2.7665 * * *(0.4001)$ & $3.7122 * * *(0.3638)$ & $2.6265 * * *(0.3505)$ & $4.7696 * * *(0.6215)$ \\
mtb & $0.0437 * * *(0.0057)$ & $0.0109 *(0.0063)$ & $0.0270 * * *(0.0053)$ & $0.0505 * * *(0.0093)$ \\
leverage & $-0.6211 * * *(0.1219)$ & $-0.1867 *(0.1063)$ & $-0.4671 * *(0.1023)$ & $-0.8791 * * *(0.1783)$ \\
shrhfd10 & $-0.8492 * * *(0.1948)$ & $-0.8619 * * *(0.1266)$ & $-0.6274 * *(0.1281)$ & $-1.1501 * * *(0.2251)$ \\
soe & $0.3634 * * *(0.0525)$ & $0.2751 * * *(0.0378)$ & $0.2535 * *(0.0336)$ & $0.4398 * * *(0.0588)$ \\
Constant & $-20.0094 * * *(0.4751)$ & $-11.6611 * *(0.3106)$ & $-14.5560 * * *(0.4030)$ & $-25.6177 * * *(0.7283)$ \\
Year FE & YES & YES & YES & YES \\
Industry FE & YES & YES & YES & YES \\
Observations & 11,305 & 11,305 & 11,304 & 11,304 \\
R2 & 0.236 & 0.187 & 0.232 & 0.234 \\
\hline
\end{tabular}

Notes: Robust standard errors are presented in parentheses; ${ }^{* *} p<0.01,{ }^{* *} p<0.05, * p<0.1$.

\section{Conclusions}

Whether and how to assume social responsibility is the result of decisions made by senior managers of corporates, but this decision-making process is a black box, which is difficult to study. Based on previous studies, and analyzed from the perspective of higher-order theory, this paper holds that the background characteristics of senior executives can explain this decision-making process to some extent, and the CSR behaviors of enterprises can be predicted through some characteristics of senior executives, such as age, gender and tenure. In view of this, this paper proposes a new analytical approach, that is, it discusses the possible relationship between executive education and corporate social responsibility, so as to provide a good idea for the cross-research of talent training and corporate social responsibility. In addition, this study may provide a basis for selecting suitable executives for those enterprises that wish to effectively fulfill their social responsibilities.

In particular, on the basis of the existing research, based on the "Upper Echelon Perspective", taking the Chinese A-share listed companies as a sample, this paper selects the 2008-2015 annual data and studies whether executives' level of education can promote the implementation of corporate social responsibility. Through the empirical research, the following conclusions are obtained: (1) The CEO's level of education is positively correlated with the level of corporate social responsibility. (2) When the CEO is also the chairman, the CEO's level of education has a greater positive effect on CSR than those are not chairman. (3) In state-owned enterprises, the CEO's level of education plays a greater role in the positive promotion of the CSR than non-stated-owned enterprises. (4) When the CEO has studied or worked abroad, the CEO's level of education has a greater positive effect on the CSR than those who do not have overseas experience.

It is difficult for corporates to adapt to the rapidly changing social environment. Numerous facts have proved that corporates must fulfill their social responsibilities if they want to achieve sustainable development, and the effective implementation of corporate social responsibility as a corporate strategy will also be affected by the characteristics of executives. Therefore, in the new environment of corporate social responsibility construction, we should pay attention to the power of corporate executives, especially executives' level of education, which will be conducive to expanding the new ideas of talent training and cross-research in the field of corporate social responsibility. In addition, we should adopt a comprehensive view of corporate social responsibility. Making donations, public welfare and charity are only part of corporate social responsibilities. Corporates should fulfill their social responsibilities by providing reassuring products and good services for society and consumers, and they should refer to different dimensions of social responsibility to completely and effectively fulfill their social responsibility.

\section{Appendix}

Table 7. Definitions of Variables.

\begin{tabular}{ll}
\hline Panel A: CSR Performance & \\
\hline Variable Name & Definitions of Variables \\
\hline CSR Score & Summation of the disclosure of 7 CSR items, including Staff protection, Delivery protection, Customer protection, \\
CSR Disclosure & Environment protection, Public relations, System construction, Work safety \\
\hline
\end{tabular}




\begin{tabular}{|c|c|}
\hline \multicolumn{2}{|l|}{ Panel A: CSR Performance } \\
\hline Variable Name & Definitions of Variables \\
\hline Staff protection & Dummy variable, $=1$ if a firm discloses staff protection in a CSR report \\
\hline Delivery protection & Dummy variable, $=1$ if a firm discloses delivery protection in a CSR report \\
\hline Customer protection & Dummy variable, $=1$ if a firm discloses customer protection in a CSR report \\
\hline Environmental protection & Dummy variable, $=1$ if a firm discloses environmental protection in a CSR report \\
\hline Public relations & Dummy variable, $=1$ if a firm discloses public relations in a CSR report \\
\hline System construction & Dummy variable, $=1$ if a firm discloses system construction in a CSR report \\
\hline Work safety & Dummy variable, $=1$ if a firm discloses work safety in a CSR report \\
\hline \multicolumn{2}{|l|}{ Panel B: CEO Characteristics } \\
\hline Variable Name & Definitions of Variables \\
\hline ceo_age & Age of CEO \\
\hline ceo_degree & $\begin{array}{l}\text { CEO's level of education, } 1=\text { Secondary and below secondary schools, } 2=\text { Junior College, } 3=\text { Undergraduate, } 4= \\
\text { Master, } 5=\text { Doctor, } 6=\text { Others }\end{array}$ \\
\hline ceo_business & Dummy variable, $=1$ if the $\mathrm{CEO}$ has a business major background \\
\hline ceo_social & Dummy variable, $=1$ if the CEO has a social major background \\
\hline ceo_technology & Dummy variable,$=1$ if the CEO has a technology major background \\
\hline ceo_oversea & Dummy variable, $=1$ if the $\mathrm{CEO}$ has overseas experience \\
\hline ceo_female & Dummy variable, $=1$ if the $\mathrm{CEO}$ is female \\
\hline ceo_tenure & Tenure of CEO \\
\hline \multicolumn{2}{|l|}{ Panel C: Firm Characters } \\
\hline Variable Name & Variable Definition \\
\hline lnat & Logarithm of total assets, $=\ln ($ total assets $)$ \\
\hline roa & Return on assets, $=$ net income/total assets \\
\hline $\mathrm{mtb}$ & Market to book ratio, $=$ book value/market value \\
\hline leverage & Leverage, $=$ total debt/total assets \\
\hline shrhfd 10 & Ownership concentration, $=$ Herfindahl index of the top ten shareholders' shareholding ratio \\
\hline soe & Dummy variable, $=1$ if a firm is a state-owned company \\
\hline
\end{tabular}

Table 8. CEO's level of education and CSR sub-performance.

\begin{tabular}{|c|c|c|c|c|c|c|c|}
\hline & Staff & Delivery & Customer & Environment & Public & System & Work \\
\hline & (1) & $(2)$ & (3) & (4) & (5) & (6) & (7) \\
\hline & Probit & Probit & Probit & Probit & Probit & Probit & Probit \\
\hline ceo_degree & $0.1109 * * *(0.0179)$ & $\begin{array}{l}0.1058 * * * \\
(0.0182)\end{array}$ & $\begin{array}{l}0.1208 * * * \\
(0.0179)\end{array}$ & $\begin{array}{l}0.1043 * * * \\
(0.0179)\end{array}$ & $0.1139 * * *(0.0180)$ & $0.0200(0.0246)$ & $\begin{array}{l}0.1080 * * * \\
(0.0188)\end{array}$ \\
\hline ceo_age & $0.0028(0.0022)$ & $\begin{array}{l}0.0045 * \\
(0.0023)\end{array}$ & $\begin{array}{l}0.0039 * \\
(0.0022)\end{array}$ & $\begin{array}{l}0.0036 \\
(0.0022)\end{array}$ & $0.0029(0.0022)$ & $-0.0009(0.0030)$ & $\begin{array}{l}0.0061 \\
* * *(0.0023)\end{array}$ \\
\hline ceo_female & $-0.1931 * *(0.0764)$ & $\begin{array}{l}-0.2385 * * * \\
(0.0849)\end{array}$ & $\begin{array}{l}-0.1731 \\
* *(0.0759)\end{array}$ & $\begin{array}{l}-0.2282 * * * \\
(0.0786)\end{array}$ & $-0.2060 * * *(0.0776)$ & $-0.1068(0.1113)$ & $\begin{array}{l}-0.3117 \\
* * *(0.0893)\end{array}$ \\
\hline ceo_tenure & $0.0012 * *(0.0005)$ & $\begin{array}{l}-0.0000(0.000 \\
5)\end{array}$ & $\begin{array}{l}0.0009 \\
(0.0005)\end{array}$ & $\begin{array}{l}0.0015 * * * \\
(0.0005)\end{array}$ & $0.0012 * *(0.0005)$ & $0.0002(0.0007)$ & $\begin{array}{l}0.0005 \\
(0.0005)\end{array}$ \\
\hline ceo_oversea & $0.0397(0.0615)$ & $0.0825(0.0609)$ & $\begin{array}{l}0.0267 \\
(0.0613)\end{array}$ & $\begin{array}{l}0.0755 \\
(0.0615)\end{array}$ & $0.0553(0.0614)$ & $0.0018(0.0845)$ & $\begin{array}{l}0.1321 * * \\
(0.0626)\end{array}$ \\
\hline lnat & $0.5947 * * *(0.0189)$ & $\begin{array}{l}0.4554 * * * \\
(0.0178)\end{array}$ & $\begin{array}{l}0.5645 * * * \\
(0.0185)\end{array}$ & $\begin{array}{l}0.5971 * * * \\
(0.0189)\end{array}$ & $0.5804 * * *(0.0187)$ & $0.2261 * * *(0.0199)$ & $\begin{array}{l}0.5544 * * * \\
(0.0185)\end{array}$ \\
\hline roa & $2.6537 * * *(0.3511)$ & $\begin{array}{l}2.8091 * * * \\
(0.3556)\end{array}$ & $\begin{array}{l}2.8041 * * * \\
(0.3519)\end{array}$ & $\begin{array}{l}2.5303 * * * \\
(0.3530)\end{array}$ & $2.9961 * * *(0.3553)$ & $2.1344 * * *(0.4501)$ & $\begin{array}{l}1.9512 * * * \\
(0.3601)\end{array}$ \\
\hline $\mathrm{mtb}$ & $0.0259 * * *(0.0053)$ & $\begin{array}{l}0.0139 * * \\
(0.0055)\end{array}$ & $\begin{array}{l}0.0217 * * * \\
(0.0053)\end{array}$ & $\begin{array}{l}0.0269 * * * \\
(0.0053)\end{array}$ & $0.0217 * * *(0.0055)$ & $-0.0005(0.0063)$ & $\begin{array}{l}0.0212 * * * \\
(0.0057)\end{array}$ \\
\hline leverage & $\begin{array}{l}-0.4852 * * * \\
(0.1025)\end{array}$ & $\begin{array}{l}-0.3277 * * * \\
(0.1026)\end{array}$ & $\begin{array}{l}-0.4517 * * * \\
(0.1014)\end{array}$ & $\begin{array}{l}-0.4632 * * * \\
(0.1029)\end{array}$ & $-0.3935 * * *(0.1018)$ & $-0.1624(0.1242)$ & $\begin{array}{l}-0.5363 * * * \\
(0.1061)\end{array}$ \\
\hline shrhfd 10 & $\begin{array}{l}-0.6118 * * * \\
(0.1281)\end{array}$ & $\begin{array}{l}-0.5474 * * * \\
(0.1332)\end{array}$ & $\begin{array}{l}-0.5884 * * * \\
(0.1278)\end{array}$ & $\begin{array}{l}-0.6633 * * * \\
(0.1291)\end{array}$ & $-0.6444 * * *(0.1288)$ & $\begin{array}{l}-0.9639 * * * \\
(0.1815)\end{array}$ & $\begin{array}{l}-0.4696 * * * \\
(0.1323)\end{array}$ \\
\hline soe & $0.2585 * * *(0.0336)$ & $\begin{array}{l}0.1183 * * * \\
(0.0355)\end{array}$ & $\begin{array}{l}0.2506 * * * \\
(0.0337)\end{array}$ & $\begin{array}{l}0.2403 * * * \\
(0.0339)\end{array}$ & $0.2334 * * *(0.0338)$ & $0.1427 * * *(0.0459)$ & $\begin{array}{l}0.2902 * * * \\
(0.0350)\end{array}$ \\
\hline Constant & $\begin{array}{l}-14.5425 * * * \\
(0.4024)\end{array}$ & $\begin{array}{l}-11.7748 * * * \\
(0.3814)\end{array}$ & $\begin{array}{l}-13.9960 * * * \\
(0.3954)\end{array}$ & $\begin{array}{l}-14.5893 * * * \\
(0.4024)\end{array}$ & $-14.3662 * * *(0.3992)$ & $\begin{array}{l}-6.4039 * * * \\
(0.4267)\end{array}$ & $\begin{array}{l}-14.0847 * * * \\
(0.4008)\end{array}$ \\
\hline Year FE & YES & YES & YES & YES & YES & YES & YES \\
\hline Industry FE & YES & YES & YES & YES & YES & YES & YES \\
\hline Observations & 11,304 & 11,304 & 11,304 & 11,304 & 11,304 & 11,234 & 11,293 \\
\hline $\mathrm{R} 2$ & 0.231 & 0.161 & 0.217 & 0.230 & 0.228 & 0.0838 & 0.227 \\
\hline
\end{tabular}

Notes: Robust standard errors are presented in parentheses; $* * * p<0.01, * * p<0.05, * p<0.1$. 
Table 9. CEO's level of education and CSR forward performance.

\begin{tabular}{|c|c|c|c|c|}
\hline & \multicolumn{2}{|l|}{ CSR Score } & \multicolumn{2}{|l|}{ CSR Disclosure } \\
\hline & (1) & $(2)$ & (3) & (4) \\
\hline & OLS & Poisson & Probit & Logistic \\
\hline ceo_degree & $0.1560 * * *(0.0293)$ & $0.0872 * * *(0.0210)$ & $0.0842 * * *(0.0206)$ & $0.1451 * * *(0.0360)$ \\
\hline ceo_age & $0.0080 * *(0.0037)$ & $0.0043(0.0027)$ & $0.0039(0.0026)$ & $0.0054(0.0044)$ \\
\hline ceo_female & $-0.3338 * * *(0.1122)$ & $-0.2542 * *(0.1117)$ & $-0.2418 * * *(0.0898)$ & $-0.4017 * *(0.1568)$ \\
\hline ceo_tenure & $0.0023 *(0.0012)$ & $0.0010(0.0007)$ & $0.0016 *(0.0009)$ & $0.0028 *(0.0015)$ \\
\hline ceo_oversea & $0.1101(0.1140)$ & $0.0659(0.0762)$ & $0.0717(0.0767)$ & $0.1051(0.1334)$ \\
\hline roa & $4.1487 * * *(0.4545)$ & $4.1918 * * *(0.3626)$ & $3.1964 * * *(0.4120)$ & $5.7957 * * *(0.7197)$ \\
\hline $\mathrm{mtb}$ & $0.0502 * * *(0.0068)$ & $0.0173 * * *(0.0061)$ & $0.0378 * * *(0.0059)$ & $0.0689 * * *(0.0101)$ \\
\hline leverage & $-0.4243 * * *(0.1358)$ & $-0.0888(0.1090)$ & $-0.3580 * * *(0.1166)$ & $-0.7087 * * *(0.2040)$ \\
\hline shrhfd10 & $-0.8775 * * *(0.2251)$ & $-0.8130 * * *(0.1359)$ & $-0.4758 * * *(0.1501)$ & $-0.8640 * * *(0.2574)$ \\
\hline soe & $0.3032 * * *(0.0609)$ & $0.2321 * * *(0.0408)$ & $0.2112 * * *(0.0388)$ & $0.3624 * * *(0.0663)$ \\
\hline Constant & $-20.1083 * * *(0.5146)$ & $-10.6941 * * *(0.3176)$ & $-14.2434 * * *(0.4564)$ & $-24.6286 * * *(0.8261)$ \\
\hline Year FE & YES & YES & YES & YES \\
\hline Observations & 7,434 & 7,434 & 7,434 & 7,434 \\
\hline $\mathrm{R} 2$ & 0.264 & 0.182 & 0.227 & 0.229 \\
\hline
\end{tabular}

Notes: Robust standard errors are presented in parentheses; ${ }^{* * *} p<0.01, *^{*} p<0.05, * p<0.1$.

\section{References}

[1] Campbell, J. L. Why would corporations behave in socially responsible ways? An institutional theory of corporate social responsibility. Acad. Manag. Rev. 2007, 32: 946-967.

[2] Chapple, W.; Moon, J. Corporate Social Responsibility (CSR) in Asia: A Seven-Country Study of CSR Web Site Reporting. Bus. Soc. 2005, 44: 415-441.

[3] Jones, T. M.; Wicks, A. C. Convergent stakeholder theory. Acad. Manag. Rev. 1999, 24: 206-221.

[4] Orlitzky, M.; Schmidt, F. L.; Rynes, S. L. Corporate social and financial performance: A meta-analysis. Toward Integrative Corporate Citizenship; Palgrave Macmillan: Basingstoke, UK, 2008.

[5] Donaldson, T.; Dunfee, T. W. Ties that bind in business ethics: Social contracts and why they matter. J. Bank. Financ. 2002, 26: $1853-1865$.

[6] Carroll, A. B. A three-dimensional conceptual model of corporate performance. Acad. Manag. Rev. 1979, 4: 497-505.

[7] Wood D. J. Corporate Social Performance Revisited [J]. Academy of Management Review, 1991, 16 (4): 691-718.

[8] Sheldon O. The philosophy of management. M. Eastsussexs. Psychology Press, 2003: 55-57.

[9] Davis, K. The case for and against business assumption of social responsibilities. Acad. Manag. J. 1973, 16: 312-322.

[10] Mcwilliams, A.; Siegel, D. Corporate social responsibility: A theory of the firm perspective. Acad. Manag. Rev. 2001, 26: $117-127$.

[11] Schneiberg, M. Political and Institutional Conditions for Governance by Association: Private Order and Price Controls in American Fire Insurance. Politics Soc. 1999, 27: 67-103.

[12] Friedman, Milton. The Social Responsibility of Business is to Increase its Profits. J. New York Times Magazine, 2007, 13: 173-178.
[13] Jensen, M. C. Value maximization, stakeholder theory, and the corporate objective function. J. Appl. Corp. Financ. 2010, 22: 11.

[14] $\mathrm{Zu}, \mathrm{L}$; Song, L. Determinants of managerial values on corporate social responsibility: Evidence from China. J. Bus. Ethics 2009, 88: 105-117.

[15] Khan, A. Corporate governance and corporate social responsibility disclosures: Evidence from an emerging economy. J. Bus. Ethics 2013, 114: 207-223.

[16] Sanders, G. Behavioral responses of CEOs to stock ownership and stock option pay. Acad. Manag. J. 2001, 44: 477-492.

[17] Marz; Joachim W., T. L. Powers, and T. Queisser. Corporate and Individual Influences on Managers' Social Orientation. $J$. Journal of Business Ethics, 2003, 46: 1-11.

[18] Greening, D. W.; Gray, B. A. Testing a model of organizational response to social and political issues. Acad. Manag. J. 1994, 37: 467-498.

[19] Ramus, C. A.; Steger, U. The roles of supervisory support behaviors and environmental policy in employee "ecoinitiatives" at leading-edge European companies. Acad. Manag. J. 2000, 43: 605-626.

[20] Daboub, A. J.; Rasheed, A. M. A.; Gray, P. D. A. Top management team characteristics and corporate illegal activity. Acad. Manag. Rev. 1995, 20: 138-170.

[21] Deckop, J. R.; Merriman, K. K.; Gupta, S. The Effects of CEO Pay Structure on Corporate Social Performance. J. Manag. 2006, 32: 329-342.

[22] Dutton, J. E.; Duncan, R. B. The creation of momentum for change through the process of strategic issue diagnosis. Strateg. Manag. J. 1987, 8: 17.

[23] Aguinis, H.; Glavas, A. What we know and don't know about corporate social responsibility: A review and research agenda. J. Manag. 2012, 38: 932-968.

[24] Hambrick, D. C.; Mason, P. A. Upper echelons: The organization as a reflection of its top managers. Acad. Manag. Rev. 1984, 9: 193-206. 
[25] Thomas; Simerly, R. L. Internal determinants of corporate social performance: The role. of top managers. J. Academy of Management Proccedings, 1995, 2: 411-415

[26] Wiersema; Margarethe F.; K. A. Bantel. Top management team demography and corporate strategic change. J. Academy of Management Journal. 1992, 35: 91-121.

[27] Oh, W. Y.; Chang, Y. K.; Martynov, A. The effect of ownership structure on corporate social responsibility: Empirical evidence from Korea. J. Bus. Ethics 2011, 104: 283-297.
[28] Gao yongqiang; Chen yajing; zhang yunjun. "red scarf" or "green scarf": a study on charitable donation motivation of private enterprises. J. World management.2012, 8: 106-114.

[29] Goins S.; Gruca T. S. Understanding Competitive and Contagion Effects of Layoff Announcements. J. Corporate Reputation Review.2008, 11: 12-34.

[30] Haniffa, R. M.; Cooke, T. E. The impact of culture and governance on corporate social reporting. J. Account. Public Policy 2005, 24: 391-430. 